Session 2451

\title{
A SYSTEMS ENGINEERING MODEL TO MANAGEMENT AND ABATEMENT OF NONPOINT SOURCE POLLUTION
}

\author{
Bahador Ghahramani, Ph.D., P. E., CPE \\ Engineering Management Department \\ School of Engineering \\ University of Missouri-Rolla \\ Rolla, MO 65409-0370 (USA) \\ Tel; (573) 341-6057 \\ Fax: (573) 341-6567 \\ E-mail : ghahrama@umr.edu \\ Douglas M. Mattox, Ph.D. \\ Ceramic Engineering \\ University of Missouri-Rolla \\ Rolla, MO 65409-0370 (USA) \\ Tel: (573) 341-4402 \\ Fax: (573) 341-6934 \\ E-mail: dmattox@umr.edu
}

\begin{abstract}
Management of nonpoint source pollution management, consisting primarily of education and regulatory efforts, has had little success to date. Indeed, nonpoint source pollution is getting worse, not better, and the Environmental Protection Agency rates it as the leading cause of water quality problems. We must deal with the problems through a systems approach to achieving workable, feasible solutions. Unlike point source input, where the levels, quantities, and consistency of loading are known, nonpoint source pollution must be modeled as an environmentally open system that is constantly changing. Successful management of nonpoint pollution requires a systems approach for applying general land management practices to specific, unique watersheds focusing on identifying the specific objectives, increasing participation of the affected people in the development process, and applying continuous refinements and improvements once the watershed's management system is emplaced. This paper proposes a more holistic approach that will result in robust methods for modeling, implementing, and assessing the control and abatement of nonpoint source pollution.
\end{abstract}




\section{INTRODUCTION}

Nonpoint source (NPS) pollution has been identified as one of the primary concerns relative to our nation's water and environmental quality. The Environmental Protection Agency (EPA) states that nonpoint source contamination is the main reason that approximately 40 percent of our lakes, rivers, and estuaries are not clean enough to meet basic uses such as fishing or swimming (EPA Webster). NPS is pollution that does not emanate from any one source and is, therefore, difficult to manage and control. NPS is also the result of every individual who spills oil that is washed down the gutter or improperly applies environmentally harmful fertilizers and pesticides to his lawn or farmland that eventually reach ground and surface water supplies.

The Environmental Protection Agency (EPA) and other government regulatory bodies attack all forms of pollution, including nonpoint sources of contamination, through basically a three-tiered approach. The EPA seeks pollution control through legislative regulations imposed on possible producers, application of Best Management Practices (BMP) to abate the effects, and education. This methodology of controlling pollution through water quality standards such as the Clean Water Act has worked quite successfully for controlling and regulating point sources of pollution, but falls short when dealing with nonpoint source pollution. Although the EPA has come to realize the benefits of a watershed or drainage basin based approach, it needs to assume a more holistic view to solve the problems associated with nonpoint source pollution.

Regulations can be easily monitored and enforced for point sources of pollution such as municipal sewage treatment facilities that produce discharge from a single outlet. Attempting regulatory enforcement of innumerable, minute sources from constantly changing locations is, however, nearly impossible. Furthermore, Best Management Practices must be tailored for the specific watershed for which abatement is to be implemented. There are too many factors that go into development and implementation of conservation and pollution management practices for any one general approach to work everywhere. Factors leading to water contamination differ in different locations due to such aspects as soil types and average rainfall amounts. Even the goals and desired end-state of an area can be different due to social and economic factors. Education must go beyond pollution prevention to include more technical training and empowerment to enable communities to not only prevent polluting activities, but also develop watershed based management procedures for themselves. It will be the individual farmer who becomes the "scientist" implementing and adjusting the methods and procedures for controlling nonpoint source pollution on his land. To proactively combat the decentralized and profuse environmental problems related to nonpoint sources we must take a more decentralized systems engineering approach to better define and address nonpoint source pollution management, identify critical areas of concern on which to focus, and develop and assess methods for better control and management of these areas.

In many cases, these plans will result in economic benefits through the associated costs of reduced tillage and the better utilization of fertilizers and pesticides that create a win-win situation for the producer and for water quality. 


\section{DEFINING NONPOINT SOURCE POLLUTION}

Nonpoint source pollution can basically be categorized into three major producers:

Agricultural activities, residential/ urban runoff, and construction/ mining operations. Nonpoint source pollution by its very nature is widespread and focusing on any single producer will have negligible effects on its reduction. The EPA states that two-thirds of the nation's rivers are affected by agricultural nonpoint source pollution resulting from crop production and animal raising (EPA Webster). Manure runoff from feedlots and runoff from fields containing fertilizers, pesticides, organic compounds, and soil itself cause major problems with the quality of our water supplies. These runoff events can be due to rainfall, snowfall, or in large part, to irrigation practices. The latest National Water Quality Inventory indicates "agriculture is the leading contributor to water quality impairments nationwide, degrading 60 percent of the impaired river miles and half of the impaired lake acreage surveyed by states, territories, and tribes." At the same time, urban nonpoint source runoff is the largest source of water quality impairments to surveyed estuaries (Figure 1). As Figure 1 indicates, there must be ever-increasing emphasis on the effects and criticality of nonpoint source pollution, control and abatement of it in the new millennium.

\begin{tabular}{|c|c|c|c|}
\hline \multicolumn{4}{|c|}{ Three Leading Sources of Water Quality Impairment } \\
\hline Rank & Rivers & Lakes & Estuaries \\
\hline 1 & Agriculture & Agriculture & Urban runoff \\
\hline 2 & Municipal point source & $\begin{array}{c}\text { Municipal point } \\
\text { source }\end{array}$ & $\begin{array}{c}\text { Municipal point } \\
\text { source }\end{array}$ \\
\hline 3 & $\begin{array}{c}\text { Stream/ habitat } \\
\text { changes }\end{array}$ & $\begin{array}{c}\text { Urban runoff } \\
\text { Sgriculture }\end{array}$ \\
\hline Source: Water National Quality Inventory, 1994 \\
\end{tabular}

\section{FIGURE 1, PRIMARY SOURCES OF WATER QUALITY POLLUTION.}

Point source pollution can be cleaned and controlled at its effluent point (i.e., a municipal or industrial wastewater treatment plant) so that its environmentally harmful effects are eliminated. On the other hand, nonpoint source pollution must be proactively managed. It is not feasible to attempt control of every possible effluent point in a watershed or to enforce regulatory actions against every single individual who may contribute to nonpoint pollution. Therefore, means must be developed to monitor and control nonpoint sources of pollution before pollutants reach and contaminate ground and surface water supplies. Pollution sources must be managed specifically for each topographical area. 
The primary sources of agricultural nonpoint source pollution are well documented. They include soil erosion from cropland; nutrients and pathogens that are released from improperly stored waste products of animal feeding operations or from the over-application of manure to cropland; over-application of fertilizers and pesticides; poorly managed grazing operations; and sub-optimal irrigation practices. It should not be surprising that agriculture exerts such a large influence on our aquatic resources; after all, it is the dominant feature of our national landscape. Almost 400 million acres of land are actively managed to grow crops in the United States every year. Even greater acreage supports grazing activities. The direct and inevitable association between land use and nonpoint source pollution creates challenges for the agricultural community and those of us who work with this community. In "Disasters Aren't the Problem -The Real Environmental Catastrophe Is the Slow Creep of Crud, "author Michael Parfait argued that "ruination" proceeds from "small events -- the spraying of lawns; the dumping of oil; the demand for wormless apples, beachfront cottages, shrimp and layers of packaging -- in which we all partake". It is these small events, which accumulate into the major problems, and risks, that nonpoint source pollution presents to us today.

\section{CHARACTERISTICS OF NPS POLLUTANTS}

One of the first steps in developing measures to control the problem of pollution from nonpoint sources is to identify the various types; characteristics, attributes, and methods in which pollutants affect the environment. It is only from this point that a logical and comprehensive plan can be implemented to control and abate nonpoint source contamination of our nation's water resources. The EPA states that 6 billion tons of soil are lost from farmlands each year deteriorating our farmlands and clogging our rivers and waterways. We then spend $\$ 300$ million per year dredging silt out of our waterways. The GAO has reported that soil losses from poor erosion control are 25\% worse than soil loss conditions in 1934 during the "Dust Bowl" days. This loss of soil cover is a huge problem in itself and what it carries with it compounds the problem even more.

A large amount of nutrients resulting from the application of fertilizers and untreated livestock manure either erode with the soil or leach into the subsoil and subsequently the ground water. Nutrient runoff such as phosphorus and nitrates has been increasing since the 1950's and pose numerous threats to the environment. These are fertilizers in aquatic environments just as they are on land and stimulate growth of algae and moss, which in turn can choke waterways and damage aquatic life. As recently as the July 28, 1997, edition of U.S. News and World Report, an article entitled "The Cell from Hell" was written concerning the toxic algae Pfiesteria that is killing fish and marine life along the coasts of the United States. This algae thrives on the nitrate and phosphorous pollutants from biological wastes entering the rivers and estuaries. In North Carolina and Maryland a recent outbreak led to so many dead fish on the beach that it took bulldozers to clear them. The principle culprit is the nonpoint runoff of sewage wastes from industrial-scale hog farms in the state. Another example is high nitrate levels in ground water, which have been recorded throughout the Corn Belt states of the country. This contamination has resulted in many wells exceeding safe levels of nitrates due to sorption and leaching. More than $50 \%$ of the wells in Kansas were deemed contaminated in 1989, which can lead to methemoglobinemia or "blue baby disease" in infants and possibly contribute to some types of cancer (Pitt, Clark, Farmer, \& Field). 
Pesticide contamination is another nonpoint source area of concern. Most of these chemicals are water-soluble and, as a result, easily carried with water runoff or adsorbed into the soil. Many of these chemicals will dissipate from the soil to the point where no obvious pesticidal properties remain within a year with the exception of a few such as atrizine, which can stay suspended, much longer. Pesticides are often assumed to degrade at a rate proportional to the amount present and, thus, the EPA usually refers to the pesticide's half-life when considering its dissipation period. The relation of the soil type and the chemical type will determine the adsorption, solubility, and infiltration characteristics affecting the method and speed in which the chemicals reach ground or surface water sources. The greatest pesticide mobility occurs in areas with coarsegrained or sandy soils without a hardpan layer, having low clay and organic content and high permeability. At the same time, basic (high $\mathrm{pH}$ ) pesticides become more mobile in soils having high $\mathrm{pH}$ values and vice-versa (Pitt et al.). The health risks posed by these chemical contaminants are possible linkages to cancer, nervous system disorders, birth defects, and other systemic disorders.

Organic compounds that enter our water resources primarily from livestock operations pose additional threats to the environment. Industrial and urban areas also contribute heavily to the organic load in our water as a result of stormwater runoffs collecting petroleum-based (organic carbon) products off roads and streets that are subsequently carried into our water supply. There are three principle mechanisms leading to the removal and dissipation of organics:

1. Volatilization is the organics' physical and chemical properties enabling the organic to interact with the atmosphere.

2. Sorption is the ability of the organic molecules to bond with other molecules and can take the form of several types of bond.

3. Decomposition through degradation is the process in which the organic is chemically or biologically broken down. It includes hydrolysis and photodegradation as well as degradation from biological microorganisms (Pitt et al.). This method accounts for the majority of organic decomposition and there are many additional factors that go into this process (Figure 2). Organics can stay suspended in water for long periods before settling, which increases the related environmental hazards.

\begin{tabular}{|l|c|c|}
\hline \multicolumn{1}{|c|}{ FACTORS } & PATHOGEN & EFFECT \\
\hline $\mathrm{pH}$ & Bacteria & $\begin{array}{c}\text { Shorter survival in } \mathrm{pH} 5 \\
\& \text { below (acidic) }\end{array}$ \\
\hline Moisture content & Bacteria \& entervirus & $\begin{array}{c}\text { Longer survival in moist } \\
\text { soils }\end{array}$ \\
\hline Temp. & Bacteria \& viruses & $\begin{array}{c}\text { Longer survival at low } \\
\text { temp. }\end{array}$ \\
\hline Sunlight & Bacteria \& viruses & $\begin{array}{c}\text { Shorten survival at soil } \\
\text { surface }\end{array}$ \\
\hline Organic matter & Anaerobic bacteria \& viruses & $\begin{array}{c}\text { Longer survival \& } \\
\text { possible regrowth if } \\
\text { enough organic present }\end{array}$ \\
\hline
\end{tabular}

FIGURE 2, DECOMPOSITION AND DEGRADATION FACTORS. 
Along with organic compounds and often associated with organics are pathogenic microorganisms. Many factors affecting the removal of pathogens and the ability to contaminate water supplies (See Figure 2). Viral and bacterial pathogens pose great risk of disease to humans ranging from salmonella to viruses causing hepatitis and meningitis.

Metals and minerals pose another primary risk to the environment from nonpoint sources such as mining operations. Mineral salts can dissolve in water and rapidly infiltrate into water resources. Heavy metals can leach into the ground water from various nonpoint sources bonding with water molecules under certain conditions. Many metals are known to have harmful effects on fish, animal, and human populations while salts can "kill" the ground they accumulate in and prevent any plant growth.

These major types of nonpoint source pollution are dependent on many factors. The problem of nonpoint source pollution is difficult to encompass. Yet, one can begin to relate specific attributes to the different causes of contamination, which in turn allows for developing models and measures for control.

\section{APPLYING A SYSTEMS APPROACH}

A general framework for improving the management of lands and reducing the delivery of pollutants should involve efforts to:

1. Maintain and enhance soil quality,

2. Improve the precision and efficiency of inputs, including nutrients and crop and lawn protection products, and

3. Reduce the urban and agricultural delivery of sediment, nutrients, and pathogens due to erosion, runoff, and drainage. Still, the specific strategies that are most effective at achieving these goals will depend upon the site-specific soil, landscape, and hydrologic characteristics of each farm and watershed. No single management practice is a "cure for nonpoint source pollution and each watershed presents an entirely different problem to be solved.

One must identify the critical area (i.e., watershed or basin) to be control or lesson the effects in that critical area, and develop a comprehensive plan for implementing measures area wide in order to have lasting real effects. The control measures and proposals must be developed with the social and economic benefits in mind since the best means for ensuring successful implementation of environmental stewardship is to relate the problem directly to the people and give them ownership of the solutions. The immense scale and dynamics associated with the different characteristics and parameters of nonpoint source pollution demands a more holistic, systems approach.

The first step using a systems approach to problem solving is problem formulation and needs analysis. Nonpoint pollution must be identified in relation to the types of topography, economy, and possible pollutant producers. A hog farm in Iowa surrounded by acres of corn will have entirely different solution needs than an apple orchard in Washington State of the same dimensions. The critical area must be defined since the viability of a project is defined in terms 
of the entire watershed and not any single source of contamination. At the heart of this is extensive research and documentation of water quality problems and their sources in order to develop a well-defined baseline in which to begin.

Next, the setting of objectives and overall project plan must begin. Specific project objectives and goals must be defined in terms of short and long-term environmental goals as well as social, economic, and geographic goals. Furthermore, management must "power-down" to the potential participants and community members involved. It will be the individual stewards of the land conducting the research and implementing management practices. The Snyder Evaluation Model (Alien) is one such evaluation process, which lends itself to involving participants as coevaluators through a three-stage process of evaluation: process, outcome, and short-cycle (Figure 3). This involves the concept of "learning by doing" since initial objectives and procedures are likely to result in both intended and unintended effects. While the unintended effects are to be minimized, the project is developed with a long-term, idealistic focus for refinement and continuous improvement.

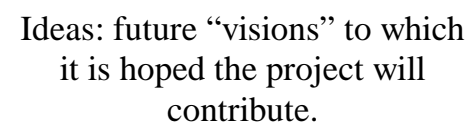
contribute.

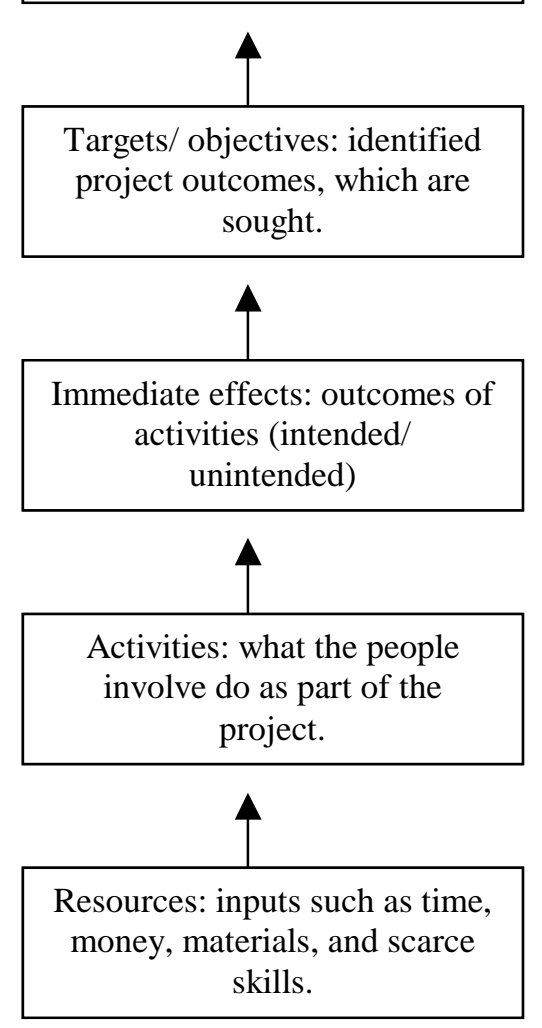

\section{OUTPUTS}

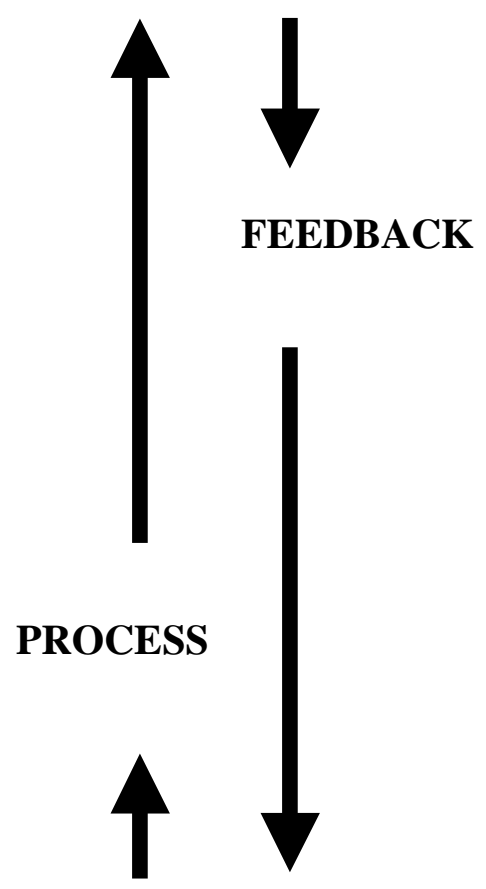

INPUTS

FIGURE 3, SNYDER EVALUATION MODEL. 
At the same time, funding must be secured and agency roles such as that of the EPA must be clarified to ensure adequate delineation of responsibilities. A critical phase of project development is model building. One must design a data-collection, monitoring, and evaluation model that enable studying the critical area as well as continuous revision and improvement once systems are emplaced. This can be done with geographic information system (GIS) tools, simulation, and measuring devices. The specific characteristics of the primary pollutants identified in problem analysis can be related to the system attributes that will drive criteria development. These attributes are the methods in which contamination by the major pollutants occurs: runoff, sorption, bonding, leaching, solubility, half-life, degradation, and/or relation to atmospheric conditions. Thus, the variables (PPM contaminants in water) and model parameters (runoff events) can be associated with the accumulation of nonpoint source pollution and the predefined environmental thresholds (EPA standards) for such pollutants.

Data collection can take place at this stage to measure the current environment's water quality and potential threats. This will, in turn, lead to verification and validation of the problem analysis and modeling process. Should the data not verify and validate the model, the problem, goals and model can be adjusted and refined as necessary since the system is a continually improving process. Once the model and system achieve validity, an experimental design can be created. It can be based on the general land treatment and Best Management Practice (BMP) approaches, but will also apply a much more holistic approach based on the specific watershed system that has been constructed. Efforts can also be concentrated and exercised more efficiently on a small scale. For example, if only a small portion of the watershed produces a wide majority of the pollution, management practices can be tailored to this area. It is much more feasible and cost effective to achieve this than a $100 \%$ solution which would be impossible to design given the constantly changing state of nonpoint pollution. Should the experimental design meet the project objectives and attain the intended effects, full-scale implementation can then occur along with documentation of results. This will allow for performing continuous assessment and improvements to the system parameters (See Figure 4). This systems approach results in the most efficient and productive means of managing nonpoint source pollution since it accounts for all factors within the specific watershed or basin.

\section{CONCLUSIONS}

Conservation efforts have shown limited success in implementing general soil control practices such as terracing, improved tillage methods, and use of settling basins, but sedimentation from runoff is still the leading source of water quality impairment. This is primarily because specific watersheds need specific treatment and control procedures. Much more needs to be done in environmental management to ensure that all areas contributing significant runoff to water quality problems are addressed. Furthermore, any individual occurrence of nonpoint source pollution is negligible and environmental management must take this into account. In order to achieve appropriate management, an individualized, systems approach to watershed management must be adopted that involves all participants with the design, development, and implementation of control and abatement procedures. These procedures must be robustly tailored specifically for the needs and requirements of the watershed's principle uses, topography, and stated objectives in order to maximize effectiveness. 
Otherwise, control of nonpoint source pollution will remain where it is today tied up in bureaucratic policy procedures that attempt regulation, not functional management.

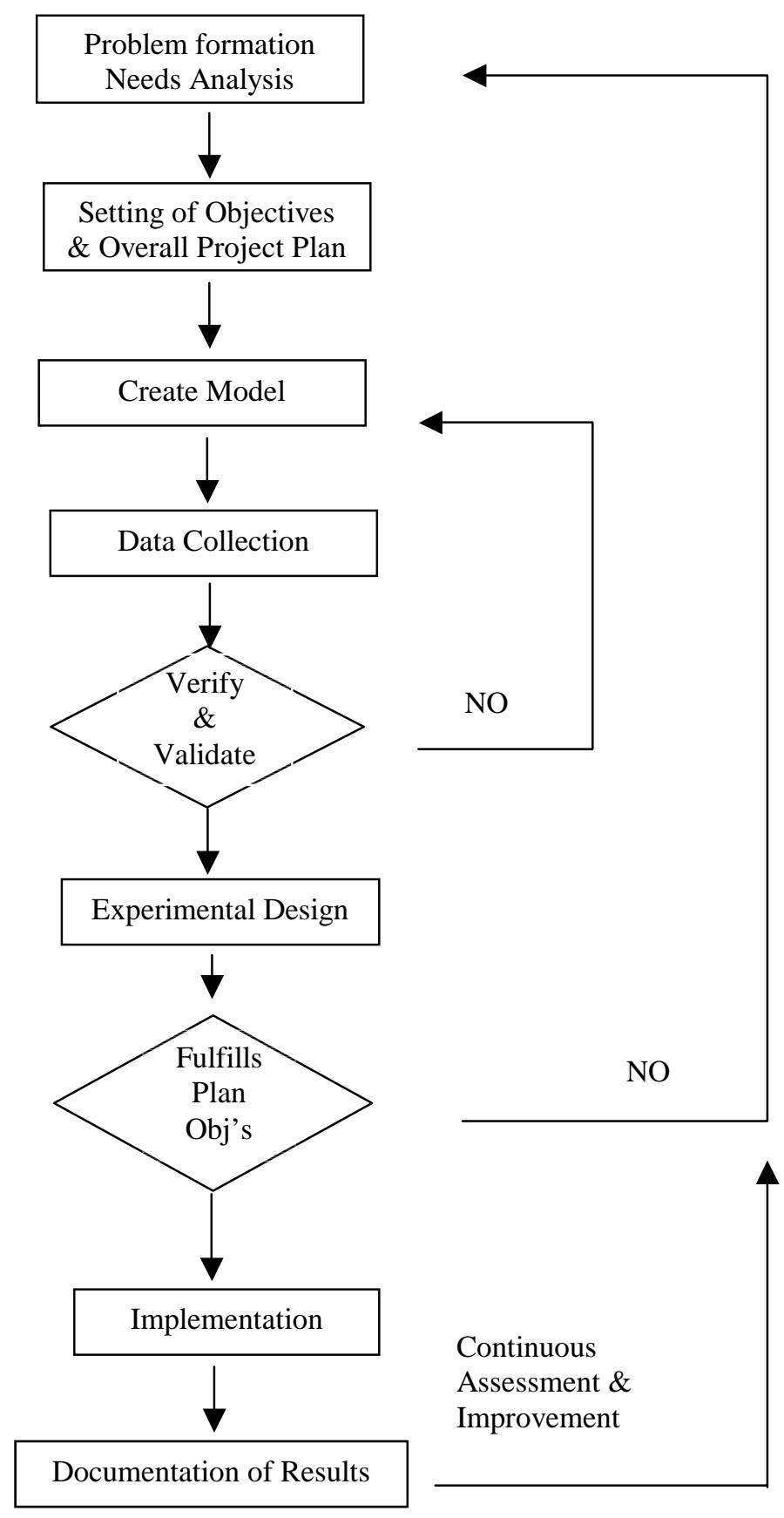

FIGURE 4, SYSTEMS APPROACH TO PROBLEM SOLVING. 


\section{REFERENCES}

[1] B. S. Blanchard, and W. J. Fabrycky, System Engineering and Analysis, New Jersey: Prentice-Hall, 1990.

[2] O. J. H. Bosch, W. J. Alien, and R. S. Gibson, Monitoring as an Integral Part of Management and Policy Making, Manaaki Whenua- Landcare Research, 1997. (URL: www.landcare.cri.nz)

[3] J. A. Gale, D. L. Osmond, D. E. Line, J. Spooner, and J. A. Arnold, Planning and Managing a Successful Nonpoint Source Pollution Control Project, North Carolina Cooperative Extension Service, North Carolina State University College of Agricultural and Life Sciences, 1995.

[4] R. C. Loehr, C. Raymond, D. A. Haith, M. F. Walter, and C. S. Martin, Best Management Practices for Agriculture and Silviculture, Ann Arbor, MI: Ann Arbor Science Publishers, 1979.

[5] M. Parfit, Disasters Aren't the Problem-The Real Environmental Catastrophe Is the Slow Creep of Crud, Office of Water Nonpoint Source News/ Notes. (URL: www.epa.gov/owow/info/NewsNotes)

[6] R. Pitt, S. Dark, K. Parmer, and R. Field, Richard, Groundwater Contamination from Stormwater Infiltration. Chelsea, MI: Ann Arbor Press Inc, 1996.

[7] M. Satchell, The Cell from Hell, U.S. News and World Report 28 July, 1997.

[8] U.S. Environmental Protection Agency, Office of Water Nonpoint Source Control Branch, Managing Nonpoint Source Pollution from Agriculture, EPA841-F-96-004F. (URL: www.epa.gov/owow/nps)

[9] U.S. Environmental Protection Agency, Office of Water Nonpoint Source Control Branch, Nonpoint Source Pollution The Nation's Largest Water Quality Problem, EPA841-F-960 0 4A. (URL: www.epa.ffov/owow/nps \}

[10] U.S. Environmental Protection Agency, Office of Water Regulations and Standards, Perspectives on Nonpoint Source Pollution, Proceedings of a National Conference: Kansas City, Missouri, 1985.

\section{BIOGRAPHY OF THE AUTHORS}

Dr. Bahador Ghahramani is an Associate Professor of Engineering Management in the School of Engineering at the University of Missouri-Rolla (UMR). Prior to joining UMR he was a Distinguished Member of Technical Staff (DMTS) in AT\&T-Bell Laboratories. His work experience covers several years of academics, industry, and consulting. Dr. Ghahramani has presented and published numerous papers and is an active participant and officer of various national and international organizations and honor societies. He holds three patents the "Eye Depth Testing Apparatus", "A Method for Measuring the Usability of a System and for Task Analysis and Re-engineering", and "A Method for Measuring the Usability of a System". He has another patent pending "Emergency Marker System, Marker Device, Components Therefore and Methods of Making the Same". Dr. Ghahramani also maintains copyrights on five other AT\&T designs. Dr. Ghahramani received a Ph.D. in industrial engineering from Louisiana Tech University; an MBA from Louisiana State University; an MS in industrial engineering from Texas Tech University; M.S. in applied mathematics from Southern University; and a B.S. in industrial engineering from Oklahoma State University.

Dr. Douglas M. Mattox is a professor of Ceramic Engineering at University of Missouri-Rolla (UMR). After receiving his B.S. and Ph.D. degrees from Rutgers University, he spent ten years in industrial research and management mostly with the Westinghouse Electric Corporation, where he was last Fellow Scientist and a winner of Westinghouse Signature of Excellence Award in 1988. Professor Mattox has published more than 100 proprietary reports and 70 proprietary patent disclosures, published 3 book chapters, 31 archival papers in the open literature and been issued 12 patents to date. 